\title{
Groove Theory: A Vamp on the Epistemology of Funk
}

\section{Tony Bolden}

When asked to define funk, George Clinton once said, "If it makes you shake your rump, it's the funk." At the most basic level, the term "funk" signifies honesty and beauty of expression at the depths of human emotion. As such, funk comprises the secular counterpart of "the spirit"-what Albert Murray calls "paroxysms of ecstasy" - in black church worship. Writing about James Brown, the musicologist Teresa L. Reed makes an observation that is applicable to funk music generally. She states that the music "captures the soulful spontaneity of the Sanctified church and the animated exhortation of the Sanctified preacher. [The music] also emulates and incites an emotional intensity parallel to the Holy Spirit possession that is a trademark of the Sanctified worship service." Teddy Pendergrass makes a similar point in his memoir Truly Blessed. Recalling his childhood experiences in what he described as a "rock-'em, sock-'em, sanctified, feel-the-Spirit church," Pendergrass said, "We talk today about the innovations in rhythm made by great jazz musicians and pioneers like James Brown, but the truth is, they had nothing on a congregation going full force in praise of the Lord."' The musicologist Guthrie P. Ramsey, Jr. echoes Pendergrass's statement in his recollection of his experiences as a member of the Sanctified Band in Chicago. According to Ramsey, "Funky was the watchword . . God liked funky. Funky ministered to the people." Of course, black churches have always functioned as training repositories for black musicians, but the frenzy and kinetic expression associated with holiness churches played a disproportionate 
role in funk music. These churches emphasized Africanist worship styles, and funk music showcased many of the aesthetic sensibilities and epistemological principles that were central to their worship styles. Hence, jazz/funk guitarist James "Blood" Ulmer entitled his 1980 composition "Jazz Is the Teacher (Funk the Preacher)." Similarly, on the initial recording of "Papa's Got A Brand New Bag," the Godfather of Soul can be heard saying that he feels "like preaching." And Lyn Collins, who sang with Brown, was nicknamed Mama Feelgood and the female preacher. Her comments regarding the conceptual approach to "Think (About It)," which was a funkified womanist manifesto, typify the spirituality of funk music. Seconds before Collins's recording, Brown told her, "[W]ait, Miss Collins. ... . [W] hen you're talkin' to the women, I don't want you to just talk. I want you to do that gospel thang. You know, I want you to tell 'em, I want you to preach to "em. ..."6

\section{Introduction: Kinesis, Cognition, and Constructions of Funk}

Most discussions of funk music emphasize ideological relationships with the Black Power Movement and musical innovations that establish conceptual foundations for subsequent forms such as Afro beat and hip hop. But while such approaches are vital to understanding the larger significance of the funk genre, they often overshadow the psychosomatic construct known as the funk. In this essay, I argue that the funk/spirit - or, more simply, the funk-operates as a distinct form of black vernacular epistemology. Though often mischaracterized as a lack of rationality, the quasi-electric sensation that Clinton calls the pleasure principle should be understood as an alternative form of rationality. Poet-critic Nathaniel Mackey touches on this alterity in an interview with Paul Taylor. Responding to a question about the importance of mystical traditions in his writings, Mackey states that "by juxtaposing the mystical to reason as you do you're giving it the status and the scope of an alternative reason, much the same way in which Pascal, in that famous formulation of his, writes of the heart having reasons that reason knows nothing about. So we're talking about a recognition, even within the Western tradition, of the limits of reason, a recognition of other ways of knowing, multiple ways of knowing." Naturally, the prevailing notions of epistemology, which are based on the mind/body split promulgated by conventional notions of Christian philosophy, forecloses the possibility that sensuality is involved in the production of knowledge, that thinking can be both "sensual and abstract." However, Funkadelic's 1970 album Free Your Mind . . . And Your Ass Will Follow belies the very premise of such foreclosure, as does the subtitle of Funkadelic's 'Lunchmeataphobia ('Think! It Ain't Illegal Yet')" (1978). In point of fact, the funk is typically constructed by the phenomenological interplay between motion and emotion. The ethnomusicologist and percussionist John Miller Chernoff refers to this driving dynamism as "a basic funk energy source." Likewise, funk scholar Rickey Vincent has argued that the funk (as 
distinct from funk music) is actually an impulse. He states that it is "much more than a style[; it is a means to a style." 10 The dance scholar Jonathan David Jackson has referred to this phenomenon as sensing. In his analysis of improvisation in black social dancing, Jackson defines sensing as "the valorization of emotion as intelligent knowing. Sensing also signifies a heightened, in-the-moment" form of logic. ${ }^{11}$ The acclaimed novelist Leon Forrest made a similar observation in his analysis of dance and spirituality in black churches in Chicago. In the following passage, Forrest speculates on the extent to which holy dances have prefigured black social dances. He writes,

During these seizures, the anklebone and the hipbone, the hipbone and the backbone seem almost disconnected, so violent is the shock of the rhythm.... And one can't help but reflect on how these holy dances have influenced popular dance patterns. For under the cover of church and in the name of God, you might act out steps that you might not show at home, nor even think to attempt. But here the creative juices are up; you are encouraged to let the mind and spirit romp, roam, and reinvent. And if you are high in the ecstasy for Jesus, who knows what the body might tell the soul to reveal? ${ }^{12}$

Contrary to conventional wisdom, Forrest suggests that the frenzied atmosphere of many black churches has been as conducive to choreographic experimentation as house parties and night clubs. This emotional fervor and choreographic display, which has long been the subject of ridicule and derision, became an important aesthetic barometer in funk.

Several scholars and artists have examined the pivotal role of the body in black music. Collectively, their findings suggest that, by and large, the body functions as the primary instrument in black music, and that all other instruments function as appendages to the body. ${ }^{13}$ This is precisely ethnomusicologist Kyra D. Gaunt's argument in her groundbreaking analysis of black girls' double-dutch games. She argues, "[T] he body is a technology of black musical communication and identity. ... Extra somatic instruments (drums, flutes, violins, steel pans, and, arguably, in some circles, turntables) are acceptable media of artistic technology." ${ }^{14}$ Thus, black vernacular thinkers tend to privilege corporeal communication over abstract analysis, and their ideas are often reflected in self-reflexive forms wherein methods merge with meaning. ${ }^{15}$ As Thomas F. DeFrantz observes, "In general, black expressive cultures value the process of signification over the signified, the performance of spirituality over scriptural exegesis, talking by dancing over talking about dancing." 16 Though black dancing is typically regarded as pure entertainment, that is, devoid of meaning, DeFrantz suggests that kinesis comprises dynamic captions of black vernacular intellectualism. He argues, "Dance movements convey speech-like qualities which contain meaning beyond the formal, aesthetic shapes and sequences of movement of the body in 
motion. African diaspora dancing conveys the sense of performative utterances like those cultural theorist Eve Sedgewick cites, 'that do not merely describe, but actually perform the actions they name . .."'17 Gaunt corroborates DeFrantz's observation when she writes, "Through these games, girls learn to play with the convergence of oral-vernacular conventions from speech to song, and the 'grammatical syntax' or logic of embodied musical language - coded gesture, movement, and dance." 18 Likewise, in a section of her book entitled "Bodies Talking," journalist Natalie A. Hopkinson writes, "Bodies are also used to tell stories through dances such as the Beat Your Feet."19

Although the meanings of these three-dimensional utterances aren't always capable of being translated into words, meanings do exist. ${ }^{20}$ Gaunt addresses this critical problem by creating the term somatic onomatopoeia in her discussion of a children's game called shimmy shimmy coke-ca-pop! which riffs on Little Anthony and the Imperials" "Shimmy Shimmy Ko-Ko-Bop" (1960), and reappears as a "sampled" phrase in Nelly's "Country Grammer" (2000). According to Gaunt, somatic onomatopoeia involves "the naming of a thing or action by a vocal imitation" combined with "the rhythmic accents internally associated and felt by embodying such movement." ${ }^{21}$ At times, though, the inscriptions within these choreographic captions are sufficiently translucent to lend themselves to narrative analysis. The best example of this is Michael Jackson's famous Moonwalk. Naturally, I'm not suggesting that Jackson intended to create legible iteration. On the contrary, I'm arguing that Jackson's body-talk bespeaks a narrative that Jackson himself may not have surmised. A postmodern revision of earlier versions of the dance, the Moonwalk can be read as a choreographic narrative of political economy, revealing the contradictions between black vernacular creativity and the alienation and marginalization of black workers under American capitalism. ${ }^{22}$ To put it differently, the Moonwalk (choreo)graphs the increasing amounts of labor that blacks must produce in exchange for decreasing amounts of dollars and benefits amid deteriorating working conditions and declining job security. Jackson (re)presents the black artist-laborer as an everyman who personifies coolness and panache. He is the expressive embodiment of the Blackbyrds' 1975 jazz-funk hit "Walking In Rhythm." Indeed, the King of Pop dances so fluidly that he creates the illusion of effortlessness - this despite the fact that the dance culminates countless hours of practicing. ${ }^{23}$ The black everyman expends a considerable amount of energy, while literally moving backwards. In the context of political economy, the import of this retral motion is comparable to putting money into an empty pocket with a gaping hole at the bottom.

In her research on street funk in Dayton, Ohio, Portia Maultsby demonstrates that dance was a crucial aspect of funk musicianship. In her interview with bassist Marshall Jones of the Ohio Players, Jones suggests that he "read" black dances as (choreo)graphs. He says, "I'd always find somebody on the dance floor and I would watch how they moved. I would watch them flowing with the hips and then move. And I would get in sync with that pattern." ${ }^{24}$ Jones's statement that he got "in sync" with the dancers' movements epitomizes actionality as a form 
of cognition. Moreover, his comments are nearly identical to those of drummer Dannie Richmond who played with the legendary jazz musician Charles Mingus. For Richmond, the tap dancing of Baby Laurence constituted a repository of rhythmic inscriptions expressed as body-talk. Richmond recalls,

The band would play the head on the theme and Baby Laurence played the breaks. Little by little we worked it where at first I was just doing stop-time, fours, so that I'd memorized every lick of his. I learned that it wasn't just single strokes involved in the drums. My concept was that if you had the single strokes down, you could play anything. It's not true. It's almost true, but not totally. And the way Laurence would paradiddles along with single strokes. He could do all of that with his feet. It got to where we're doing fours together. He'd dance four, then we played threes, twos, one bar apiece, but I was copying him. I'd more or less play what he danced. I was trying to keep it in the context of melody dance and, mind you, to me that was the same as a saxophone player trying to play like Charlie Parker. ... It was a gas for me to duplicate what Laurence danced. When he switched up on me and changed the time, there was no way I could play that. ${ }^{25}$

The comments by Jones and Laurence are highly instructive. They point up black vernacular concepts of music-making, and call into question the normative presumption that sound is more important than dance by suggesting that the rhythmic complexity of black dancing can exceed that of accomplished drummers such as Richmond. Note that Richmond "copies" Laurence, just as Jones gets "in sync with [a dancer's] pattern." Although this approach to music-making has existed as long as the black presence in America, it was highlighted during the funk era in a perhaps unprecedented manner. ${ }^{26}$ Similarly, the low-down dirty blues licks and unabashedly sensual bodily movements were essential parts of blues and jazz cultures ${ }^{27}$ but because they were considered obscene by white cultural standards and bourgeois black tastes, dancers and musicians usually confined these expressions to places such as rent parties, dives, and churches where working-class blacks felt free to express their feelings according to their own dictates.

Needless to say, no artist has theorized and practiced the epistemology of funk more substantively than James Brown. Although he was an accomplished multi-instrumentalist, Brown actually led his band as a dancer. Which is to say, he communicated with band members through body-talk. Discussing his first performance with the Godfather during an interview with poet Thomas Sayers Ellis, Bootsy Collins emphasized this point. "If you noticed," he said, "it wasn't so much about his singing and screaming, it was all about his body. His moves. You had to pay attention!'”28 Brown's tour manager, Alan Leeds, came to a similar conclusion after watching old videotapes, pointing out that a lot of Brown's 
movements "were code[s] for the drummers - a certain hand signal, a certain move of the foot. Every move of the foot demanded a rim shot. Or a kick. And there certain moves of the hand that said, I want a hit here; I wanna break this down." ${ }^{29}$ The comments by Bootsy and Leeds recall Zora Neale Hurston's suggestion that black social dances function as distinct forms of ideography: They evince "dynamic suggestion. . . . [and] compelling insinuation." 30

Brown's 1965 breakthrough recording "Papa's Got A Brand New Bag" provides an exemplary illustration of the role of kinesis in the logic of funkentelechy. For Brown, the song choreographed the feelings of pride and frustration that fueled the Civil Rights Movement. But when he introduced the song to his band members, the rhythmic emphasis on the first beat of a four-beat measure was so avant-garde they couldn't apprehend it. Brown recalls, "The drummers couldn't move their sticks in their hands to the ONE two THREE four progression I asked for as a replacement to the one TWO three FOUR they had always played ... [which was] the basic rhythm of rock and roll that stretched all the way back to Chuck Berry." 31 That Brown was fully cognizant of the innovative nature of "New Bag" is not only indicated in the title, but also his exclamatory statement that prefaces the song: "This is a hit!" Yet when King Records owner Syd Nathan asked him to explain the meaning of the apparently nonsensical song, Brown confessed that he, too, was unable to explain it in words, and attributed its inspiration to a spiritual feeling. ${ }^{32}$ On the surface, Brown's confession casts suspicion on my claim regarding Brown's self-conscious artistry. However, in light of his statement that all of his music "begins with feeling," 33 it becomes clear that emotion, that is, a funk/spirit was the key ingredient of Brown's artistic method. And since "New Bag" concerns the interrelationships between the funk/spirit and choreographic self-reflexivity, it's understandable that Brown was unable to provide an analysis in abstract terms. The meaning of the song is synonymous with its methods and effects: In order to demonstrate the power of the funk, Brown had to construct it and render it in full effect.

Interestingly enough, though, Brown doesn't use the word "funk" in the song. Instead he opens the song with an invitation to a female partner to join him on the dance floor, telling her that his new bag of music generates a "swing[ing]" sensation that compels him to dance. Employing black street argot that was current at the time, the singer-persona calls attention to himself, appealing to his would-be partner to check out his innovative style. He catalogues the dances that he performs, including the Fly, Jerk, Alligator, Mashed Potatoes, and Twist. Immediately following the latter allusion, he calls attention to his performance style once again ("just like this") to demonstrate the unique nature of his art. In live performances, Brown briefly performs the Twist as alludes to the dance in the song. Perhaps the most important line of the song, however, occurs when Brown engages in a subtle form of signification and braggadocio.

Much has been made about boasting in black popular culture. Whereas conventional Western philosophy has normalized the notion that the mind and body are polar opposites, boasting is usually considered crude in mainstream 
American culture. But insofar as sensuality is intrinsic to the epistemology of funk, braggadocio and hyperbole are often viewed as endemic to black performance, particularly inasmuch as they accentuate individual talents and styles which, in turn, are typically reflected in various forms of adornment. That Collins was also known as Mama Feelgood is an indication of how highly regarded are braggadocio and show(wo)manship in black vernacular culture. At the pinnacle of a given performance, an artist demonstrates a superlative level of creativity that highlight their special talents. When this happens, the artist's distinctive flair elicits responses from audiences, and the responses inspire the artists to experiment even more demonstratively. According to the musicologist Olly Wilson, "These are moments when the artist performs a particularly unique phrase in which rhythmic, timbral, melodic, or harmonic displacement is ingenious. It is these moments that reveal the quality of the artist's musical imagination. ${ }^{\prime 34}$ Thus in Brown's "New Bag," the line "Jump back, Jack, see you later, Alligator" is actually Brown's proclamation that he has achieved an incomparable level of creativity. He aptly engages in one-upmanship, signifyin(g) on his rivals. Using the sound-image of the dance, which was performed with both hands and feet simultaneously, Brown puns on a popular rhyme: See you later, Alligator; after-while, Crocodile. Ostensibly directed to his dance partner, the line is an indirect though stinging critique of other popular band leaders. In a word, Brown is serving notice that he reigns supreme.

Brown followed "New Bag" two years later with his 1967 recording of "Cold Sweat," which many musicians and critics hailed as an important formal breakthrough in the history of funk music. However, I'm more interested here in the epistemological implications inscribed in the Godfather's oxymoronic title. Though the image of cold sweat refers specifically to the feeling that the persona's lover gives to him, the unrestrained manner in which Brown expressed emotion in the song established a thematic precedent for numerous songs thereafter. In a manner and intensity heretofore inconceivable, funk artists paid homage routinely to the funk/spirit. Sly and the Family Stone, Parliament-Funkadelic, Ohio Players, Earth, Wind, and Fire - to name a few-recorded a plethora of songs that were self-referential to the funk. Even little known artists such as Tom Browne recorded songs that heralded the unabashed celebration of the funk/spirit. In his 1980 hit recording "Funkin' for Jamaica," singer and songwriter Tonni Smith repeatedly identifies the psychosomatic sensation that she engages as Jamaica funk, while imploring listeners to open themselves up widely enough to "let it come" into their bodies. But while the pleasure principle was endemic to funk, the funk/spirit is hardly peculiar to funk music as such.

Stevie Wonder's 1976 recording of "Sir Duke" provides a case in point. A ringing tribute to the musicianship of such artists as Louis Armstrong, Count Basie, Glenn Miller, Ella Fitzgerald, and, naturally, Duke Ellington, "Sir Duke" demonstrates the fallacy of confining our correlations of the funk with the genre of funk music. With the notable exception of Armstrong, who adroitly engages the pleasure principle in his classic 1926 recording of "Heebie Jeebies," all of 
the musicians who are cited are associated with swing music of the 1930s and early 1940s. Yet Wonder suggests that these very musicians became models for him precisely because of their ability to construct what Clinton would later coin the pleasure principle, that is, pure, uncut funk. Moreover, the psychosomatic effect that Wonder ascribes to the swing of Ellington and Basie ("you can feel it all over") is synonymous with the funkiness of his own composition. Naturally, most people conceptualize "swing" and "funk" as dissimilar genres of music. But while the two styles of music may differ as markedly as their respective historical periods, the emotional referents of "swing" and "funk" are as synonymous as the words "red" and "crimson." For instance, Hopkinson considers Chuck Brown's hit "Go-Go Swing" "a funked up version of the Duke Ellington classic" "It Don't Mean a Thing (If It Ain't Got That Swing). ${ }^{35}$ Preston Love, who began playing alto saxophone in Basie's band in the early 1940s, underscores this point in his recollection of lead trumpeter Ed Lewis. According to Love, "Much of the Basie sound was Ed Lewis. He "grew up" with the original Basie style from Kansas City and captured the essence of the Basie feeling and the Kansas City charm.... Basie's was the greatest swing band with the most relaxed feeling in jazz history, and Ed always swung like no other lead trumpet probably did. We always referred to his lead as "funky," far before the word came into common usage in connection with rhythm and blues." 36

At the same time, Wonder suggests that music and movement are not necessarily isomorphic. Punning on the word "groove," he sings that success in recording ("in the groove") isn't synonymous with success with rhythm, which means putting people "in a groove." In other words, Wonder suggests that kinesis is the ultimate sign of a funky groove. Not surprisingly, his concept is nearly identical to Ellington's concept of swing. Ellington says, "No notes represent swing. You can't write swing because swing is the emotional element in the audience and there is no swing until you hear the notes. Swing is liquid, ${ }^{37}$ and though the same group of musicians may play the same tune fourteen times, they may not swing until the fifteenth time. ${ }^{" 38}$ Just as Clinton posits kinesis as the primary signification of funk, so Ellington theorizes swing as a subcutaneous construct, a sensory undercurrent manifested in kinetic expression. It is also worth mentioning that Ellington prefigures the concept of flow in hip hop-the indescribable formula of syllabic rhythms and sick rhymes that compel audiences to nod their heads to the beats.

Ellington's concept of swing is also similar to Brown's foregrounding of sensuality. But whereas Ellington stresses emotion as the defining ingredient of a swinging groove, Brown emphasizes the cognitive significance of the pleasure principle. In his song "Super Bad," his speaker boasts that he not only has this unique "emotional element, but that it feels so good he wants to shout with joy. Then the Godfather sings that the feeling (Brown calls it soul) isn't confined to the somatic sphere. Quite the contrary, as a kinetically oriented cognitive mechanism, it's integrally related to cerebral activity. Hence, Brown's "move[s] tell [him] what to do." Saxophonist Maceo Parker, who played with Brown, 
provides an additional example of this unique cognitive modality. When asked to account for his former band leader's powerful effect on his audiences, Parker both analyzed and exemplified the epistemology of funk. Brown had learned that he could utilize melodic instruments to accentuate rhythm, and had virtually turned his whole band into a drum kit. The effect was immediate. "Right away," said Parker, "your attitude is better, your attitude is lighter. You get this happy, I-wanna-dance feeling and your neck, it gets to movin' ... and ... with that in mind you go ... ${ }^{39}$ Caught up with emotion, Parker began to play his saxophone to express his ideas. That Parker says "mind" before he plays is telling. His word-choice and subsequent performance suggest that, in this context, he could convey ideas most effectively in sound. Parker's sudden shift from exegesis to kinesis sheds light on Brown's statement that funk is "a physically performed, roots-derived configuration of music that comes straight from the heart." ${ }^{\prime 40}$ Consequently, he says, "You can't tell yourself how to funk onstage; it is your musical child that takes you and the rest of the audience to another place through the delivery of a song and a dance, combing the joy that they produce together." ${ }^{\prime 41}$

\section{Balance: Contrariety as Aesthetic and Philosophical Inscription}

In a recent interview with Tavis Smiley and Cornel West, Clinton responded to a question about the "one" by saying that when everyone in the band is on the one the rhythmic effect is much stronger. But as he continued, he ventured into metaphysics. The energy created by the "one" resolves antinomies. Not only do audiences become performers through dance, but social constructs such as race, class, gender, creed and so forth are deconstructed to some extent for a fleeting moment when "we're all together as one. A lifeform. I'm for you and you for me; we for trees and we for the planet." ${ }^{\text {2 }}$ Clinton's logic is almost identical to the Africanist concept of ashe, which involves the fusion of the spirit with the body - what Amiri Baraka calls the unity of opposites. During live performances, dancers enact this principle by conjoining the body with the spirit and reaffirming (and extending) through improvised choreography the affective phrases of the music. Thus they serve a role that is analogous to witnesses in church services who testify to the powerful presence of the Holy Spirit.

So steeped is funk music in contrariety that the Ohio Players followed their hit album Honey (1975) with an album entitled Contradiction (1976). Situated in the context of romantic love as envisioned by black working-class men, the title track, sung by lead singer and guitarist Sugar Foot Bonner, is ostensibly an appeal to the speaker's lover to maintain her belief in him and the love that they share, despite the painful rumors that have circulated regarding his infidelity. Notwithstanding the masculine hegemony the song naturalizes, "Contradiction" is a scintillating illustration of axiology as well, a paralinguistic reading of the nature of dialectics. The opening line of the song establishes its fundamental premise - that contradictions constitute the very essence of life. The speaker then 
proceeds to enumerate a string of contradictions that form the basis of his life: his religious convictions keep his soul in doubt; his intention to lead a healthy life is at variance with his street lifestyle; his commitment to his relationship conflicts with his sexual attraction to other women; and his purported infidelity has lacerated his lover's feelings, so the love she feels for him is now mingled with anger and hatred. This places him in a precarious position. He's insecure, but fearful of acknowledging this because it confutes his image of cool machismo, and yet he clearly expresses his insecurity in the very act of his soulful appeal.

The contrariety in funk is one of the qualities it inherited from the blues tradition, and became one of the hallmarks of the funk aesthetic. Beginning with "What is Soul," which was recorded on Funkadelic's 1970 debut album Funkadelic, we can observe the manner in which the Funk Mob would invert black cultural alienation and orthodox American values. ${ }^{43}$ In the opening line the persona (Clinton) identifies himself as Funkadelic and tell us in a mock-harrowing voice that he "is not of your world." He defines goodness as a state of nastiness, and defines soul as "a joint rolled in toilet paper." Oxymoronic songs such as "Free Your Ass and Your Mind Will Follow" (1970), "Balance" (1972), "Miss Lucifer's Love" (1972), and "March to the Witch's Castle" (1973) are additional early recordings that illustrate funk's sheer delight in defying cultural norms and aesthetic conventions, including those among blacks. ${ }^{44}$

Several funk musicians have mentioned Jimi Hendrix as an important influence on their music. Like many of the musicians who admired him, contrariety was crucial to his aesthetic. Born in Seattle, Washington in 1942, Hendrix was enamored as a youth by country-born blues singers. He listened assiduously to blues stalwarts such as Robert Johnson, Howling Wolf, and Muddy Waters during a period when increasing numbers of black youth conceptualized hipness in terms of black urban experiences, especially the soulful sounds of rhythm and blues, not to mention the dances and fashion that accompanied it. By the early 1960s, many blacks in large urban areas not only considered the blues "country" but also politically reactionary. Moreover, many blacks wrongfully envisioned rock as an expression of whiteness. Yet Hendrix flouted social conventions by commingling musical forms and cultural styles that many people misread as mutually exclusive. For Hendrix, the ultimate challenge was reconfiguring the blues and creating what he called "a today's type of blues," ${ }^{45}$ a postmodern form that illustrated kaleidoscopes of contrasting sentiments and shifting points of view in American society. By injecting large doses of dirty blues stank into the acid rhythms of rock, Hendrix succeeded in his efforts to blue-funk rock music, while rocking the blues into the stratosphere like an electric sky church. He showcased the various techniques he learned on the chitlin' circuit, and spawned a form of blues-rock whose apotheosis was registered indelibly in songs such as "Purple Haze," "Foxy Lady," and "Hey Joe" with the Jimi Hendrix Experience; "Who Knows," "Changes," "Earth Blues," and "Machine Gun" with Band of Gypsys; and his renegade performance of "Star Spangled Banner" at Woodstock in 1969 with Gypsy Sun \& Rainbows. Having developed his craft as a journeyman while 
playing with rhythm and blues artists such as Little Richard, King Curtis, and the Isley Brothers, Hendrix delighted his audiences with blues-style showmanship. He humped his guitar, played it with his teeth, and plucked it behind his neck, while engaging in many other antics. He also adopted a psychedelic image that was consistent with free-love and free-drugs sensibilities of his predominantly white audience. Such a sharp deviation from the resplendence of the crystalclean, ghetto-fabulous-fashion that prevailed at neighborhood house parties and clubs compelled some blacks to misinterpret Hendrix's music in terms of racial apostasy. Although his music had strong appeal within innumerable interstices of black youth culture, many blacks reacted to Hendrix's music with an indifference they might have shown the Grateful Dead. This was especially true during his Jimi Hendrix Experience days when he played with British musicians Noel Redding and Mitch Mitchell. As Hendrix's former girlfriend, Fayne Pridgeon, recalls, "I've been on the scene a couple of times when people would say, 'Hey, you know Hendrix is playing ... down in the village.' And they'd say, 'Oh yeah, that's nice.' You know, just shine it on, like it ain't no big thing." 46

But while Hendrix's pre-futuristic, blues-rock virtuosity may have nonplussed certain blacks, he foregrounded the electric guitar in a manner heretofore inconceivable, and in the process he developed a novel approach to the instrument. The drummer Frank "Kash" Waddy, who played with James Brown along with bassist Bootsy Collins and his brother, guitarist Catfish Collins, before joining Parliament/Funkadelic with the Collins brothers in 1972, describes Hendrix's playing as an exceedingly rare combination of "[b]ass, rhythm, [and] lead [guitar] all into one. ${ }^{247}$ A consummate organic intellectual, Hendrix created a methodological formula for transmitting impulses of emotional color through musical sound. According to Hendrix's brother, Leon Hendrix, it was "a concept called Energy Sound Color Dynamics - which he playfully sometimes referred to as $\mathrm{E}=\mathrm{sc}^{2}$ to borrow a little style from Einstein's $E=m^{2}$ theory." 48 According to Greg Tate, "Not until hip hop moved the sound of electronically altered drums to the fore would a single instrument sound so flatten all other elements, including vocals, in a pop context. Not until technology provided a mechanism for digitized drum tracks to outshout guitars in the mix was the supremacy of the lead guitar solo as the voice of god in pop music sent packing." ${ }^{\text {49 }}$ Thus, Hendrix's artistic breakthroughs, black hippie persona, and penchant for flaunting presumed contradictions provided younger musicians such as Bootsy Collins with a new model for avant-garde aesthetics. He recollects, "[B]ack in that day, brothas wasn't cool with being freaky and ... bein' out there like that." ${ }^{50}$ For Collins, Clinton, and members of other funk groups, Hendrix's artistic experiments and outrageous stage persona were expressions of creative freedom which constituted an utter refusal to genuflect to societal norms.

Hendrix's representation of black-blues-rock personae as cultural outlaws also appealed to funk musicians. His expression of politicized alterity in "If 6 Were 9" anticipated a similar articulation in Funkadelic's "Mommy, What's a Funkadelic," and his line "play on drummer" prefigures Funkadelic's line "Fly 
on" in the song. Hendrix's emphatic transformation of cultural marginality into a psychic location of autonomy and creativity ("got my own world") served as a springboard for Funkadelic's flight-metaphor in "Mommy, What's a Funkadelic," and inasmuch as "Fly on" highlights the speaker's geopolitical severance from the terrestrial world, not to mention the resultant freedoms and pleasures this affords him ("feels good to me"), the nascent theme of Afrofuturism, which foreshadows the Funk Mob's subsequent treatments of the topic, is also an elaboration of Hendrix's idea to reconfigure received terms and meanings of marginality. Similarly, the Isley Brothers' "Ohio/Machine Gun" is soulful cover of Hendrix's "Machine Gun," which is a both a signified shout-out to the Black Panthers and a critique of the Vietnam War that Hendrix recorded live with his blue/funk group Band of Gypsys on New Year's Eve in 1969, a performance that writer and musician Greg Tate claims "changed the sound of soul music forever."51

Funk musicians routinely employed contrariety to express non-conformity, while formulating rhetorical strategies and fashioning aesthetic ideas. The most common rhetorical strategy involved inversions of various sorts, particularly forms of critical parody. Commenting on his habit of wearing a blue Klu Klux Klan robe, for instance, singer Calvin Simon of Parliament-Funkadelic said, "It was a mockery, really." 52 Clinton explained, "We said, "We gonna be the blackest, we gonna be the funkiest, we gonna be dirty." 53 This strategy facilitated the expression of a raucous, rebellious sensibility that allowed many musicians to call into question a wide range of presumptions and mythologies associated with the status quo. For instance, singer and songwriter Betty Davis recorded songs such "Whorey Angel" and Nasty Gal," satirizing conventional terms and points of view to address gender politics in sexual relationships. Funk artists also subsumed apparent oppositions to conceptualize artistic innovation. Commenting on his decision to invite child prodigy Worrell into the band, he said that "Bernie Worrell could take any groove and make it Beethoven, Bach, or any jazz thing you want it to be, right within the groove. . . . So the contradiction was done on purpose - the classical things against the real simple-minded, silly, basic." ${ }^{54}$ Funkadelic's 1978 recording of "Who Says a Funk Band Can't Play Rock?!" serves as a case in point. The song foregrounds rhetorical questions regarding accepted taboos in musicianship. For instance, according to accepted norms, funk and rock, like jazz and dancing, are mutually exclusive. But like Hendrix, Funkadelic relishes in flouting this view. The song elaborates on a theme that the band had laid down seven years earlier in its freaky, psychedelic classic "Maggot Brain." But whereas "Maggot Brain" had most notably blended the contrasting sounds of hippies and hoods in Eddie Hazel's amazing nine-minute guitar solo, on "Who Says a Funk Band Can't Play Rock?!" Clinton layers his falsetto over the guitar sounds of (black) rock guitar to add more flavor to the texture of the song. Announcing his intention to funk the rock so nasty that people can't help but move to the groove, Clinton re-energizes the term "rock and roll," employing rhythm and blues semantics that reflect black speakers' preference for verbs ("rocking" and "rolling"), while bragging about his skills: "Watch them dance." 
The capacity to accommodate contradictions, then, was essential to the ethos of funk, which was largely resistant to either/or logic naturalized by bourgeois hegemony. Perhaps the most striking example of contrariety in funk is Funkadelic's "Cosmic Slop" (1973). The song focuses on a woman who has turned to prostitution in order to support her five children. That the band addressed this topic illustrates one of the unique aspects of funk-its commitment to depict the realities and reaffirm the values, sensibilities, and aesthetics of blacks who lived in urban ghettos. The thematic complexity of "Cosmic Slop" involves its simultaneous engagement with several contradictions: male-female, rich-poor, holy-heathen, God-Devil. And since Garry Shider sings the narrative in autobiographical form, there are racial implications as well.

Reminiscent of blues singers' penchant for composing songs in first-person while addressing other people's situations, Clinton utilized Shider's maternal memory when he composed the lyrics of "Cosmic Slop." Having known Shider since he was youngster who snuck away from his mother to in indulge in mischief at his local barber shop, Clinton encouraged the young musician to approach the song as the protagonist. "[I]t was almost like he was telling my story," said Shider, "There were seven of us, we were in foster homes, and all kinda shit. My mother, I remember her out hustling to get the cash to feed us. So I could relate to it." ${ }^{55}$ The flip-side of Shider's comments, though, is that they invoke the mother-whore dyad. As with many hip hop artists today, the circumstances and conditioning of many young black men compel them to envision their own mothers as black/brown Madonnas while simultaneously categorizing other women, including mothers, as "hoes" who are fit for exploitation and differential treatment. This is not to suggest that "Cosmic Slop" promotes misogyny. Quite the contrary, it points up the fact that black music is always already implicated in the contradictions it names. In other words, "Cosmic Slop" is a beautifully rendered sonic painting of the dialectics between Africanist perspectives of the pleasure principle and the hard-core realities and racial conditioning which constrict the spatial and conceptual contexts wherein black women express pleasure. Though the song reflects a masculinist perspective, "Cosmic Slop" underscores the role of black women as primary producers of free and/or cheap labor in the U.S. In so doing, it posits the idea that black women have comprised a disproportionate share of the labor base for capitalist hegemony.

The song opens with drummer Tyrone Lampkin creating a funk-laden vibe which sets the tone for an infectious vamp that features the rock-flavored guitars of Shider and Ron Bykowski as well as a chorus of background vocalists who invoke the plaintive calls of the singer-narrator's mother. Anchored by the late Cordell "Boogie" Mosson's bass line, the vamp establishes a groove that is maintained throughout the song. But while the instrumentalists construct the quasi-electric sensation of the funk, Shider's gospel-style singing is unfathomable. The texture of his sound establishes a poignant, yet festive mood, intermingling beauty and pain as he prefaces the narrative with a captivating onomatopoeic falsetto. As the autobiographical narrator, Shider becomes the sensitive son who 
tells his mother's story, and the story he tells is markedly different from the ones typically circulated in the mass media. For the anonymous son, his mother is the walking embodiment of heroism. Though her life is a living hell, she manages to maintain an uplifting disposition and a sense of grace, while attempting to shield her children from the horrors of her life. But since the community is a collective witness, she is ultimately unable to conceal the labor that produces her wages, and, consequently, her children bear the shame and ignominy that accompany prostitution. Like the black prostitutes in Toni Morrison's novel The Bluest Eye, she is stigmatized as a jezebel by other inhabitants of the ghetto who have internalized repressive aspects of Christian morality. That there is silence regarding men's complicity in her actions - both as contraband businessmen (pimps) and consumers (johns) - is quite telling regarding the pervasiveness of misogyny in the community.

The mother's ambivalence is also noteworthy. On the one hand, she feels the bitter wages of $\sin$. On the other hand, she is sufficiently rewarded by the acts of hustling to endure the potential risks and exigencies of selling her body, not to mention the disrepute that attends it. So she prays passionately to God, beseeching His forgiveness, assuring Him that she only turned tricks for her kids, and that she intended no wrongdoing. At which point, the devil enters the narrative. He whispers in her ear, tempting her to dance the cosmic slop. The dance represents a lifestyle - cards, dice, and dominoes, not to mention parties, alcohol, and perhaps even illicit drugs and sex - which is, on its own terms, not necessarily amoral. But because race and repression are twin constructs in conventional Christian morality, these activities have been framed so that viewers misread them in pejorative terms. Blacks' refusal to abide by these dictates has often resulted in caricature, castigation, and confinement. To make matters worse, the people own and/or control relatively few cultural institutions, and therefore exercise minimal influence over social and economic policies. So while they create and/or contribute to novel linguistic, choreographic, and musical forms from which certain blacks and the larger society profit, they are constantly depicted as though they are incapable of creating anything of value. Thus, the devil figure in "Cosmic Slop" isn't a representation of evil so much as he as a Eurocentric specter of evil. In all actuality, he represents the cultural memory of Esu Elegba transposed as blue/funk iconography. Having been conditioned by missionaries' association of Esu's trickster antics and brazen sexuality with evil, many modern black Christians consider secular deviations from white cultural norms as sinful.

Even so, the contradictions of race don't erase the contradictions of gender that are reified within the narrator's male gaze. As Collins "preaches" in her recording of "Think (About It)," men can never represent women's experiences as well as women themselves. However, the ugly contradiction inscribed in "Cosmic Slop" is that agency often hinges on privilege — at least, to some degree - and the nameless mother is marginalized to such an extent that she never acquires the empowerment of authorship. We never hear her call. And yet in spite of the contradictory gender politics, the harrowing timbre and tones of Shider's voice 
bear such a tremendous resonance that his representation of the mother becomes primal and evocative. As he sings the line "I can hear my mother call," his emotions intensify with each repetition until he can only sing "mother," eliding and collapsing the remaining words into a reverberating fluctuation of sound, bordering on liquidity and glossolalia. The latter term, of course, refers to a form of paralinguistics that signifies a crescendo of spirituality which, in turn, influences aesthetics. "The singer - as caught up spiritual performer - is in control and then loosens control over his spirit. The moment that he appears to be losing control, he is actually opening himself to be taken over by the Holy Spirit. ${ }^{956}$

\section{The Cosmology of Funk: Or, Funklore as Political Allegory}

The contrariety in funk established the conceptual ground for the creation of lyrical narratives that reaffirmed black vernacular styles and sensibilities. Combining the fashion and language of black street culture with disparate elements of mainstream popular culture, especially comic strips and sci-fi television shows, Clinton created an extended Afrofuturistic narrative that elaborated on the themes of alterity and alienation which Funkadelic had expressed in "What is Soul" back in 1970. This theme, which harkens back to the antebellum spirituals when blacks imagined flying chariots capable of transporting them out of the hellish realms of slavery, became the basis for Clinton's funk operas (this historicity is accentuated in the 1975 title track of Mothership Connection where the hook of "Swing Low Sweet Chariot" is riffed-sampled in the line, "Swing down sweet chariot / stop and let me ride"). Beginning with the Mothership Connection, then, Clinton transposed Star Trek narratives into allegories of funk. But whereas alterity was associated with evil in Star Trek, otherness constituted goodness in Clinton's narratives, just as X-Men did in comic strips. Moreover, funkateers wield the all-powerful (life)force in funklore whereas in traditional sci-fi settings the force belongs to hegemonic representatives. Thus, on the Mothership album Dr. Funkenstein descends from a spaceship to restore p-funk, that is, the pure funk to humans, especially blacks. His primary funkateer, Star Child, functions as an intermediary between humans and Dr. Funkenstein, providing the former with a "mothership connection" with the funk. Not surprisingly, the people are compelled to dance, and, in turn, their corporeal expression of funkativity empowers them to levitate spiritually. To put it differently, dancing becomes a conduit for transcendence in the form of emotional release from the mendacity of the everyday living for blacks in the ghettos. Retrospecting the exhilarant impact of witnessing the landing of the mothership, singer Jeanette Washington said, "[T]o hear those people just go out of their minds ..."57 That Washington was unable to complete her sentence regarding her own observation is a testimony to the indescribable nature of the funk in full effect.

According to Clinton's funklore, ancient Afronauts had not only danced on the funk throughout entire galaxies, they also had the capacity to infuse and suffuse the funk into infinite locations and aspects of life. But because humans 
chose to abuse the funk and confuse it with negativity, it was mysteriously repossessed and deposited inside Egyptian pyramids along with pharaohs and kings until humans acquired a more amenable attitude toward the wondrous virtues of the funk. At which time, funkativity would be restored to humans in the personification of Dr. Funkenstein. But as with all sci-fi narratives, Dr. Funkenstein is counterpoised by a villain: He and his funkateers must wage battle with Sir Nose D'Voidoffunk, an arch enemy who opposes the (life)force of the groove with such resolve that he wages an incessant battle with Star Child and the Children of Production who are clones of Dr. Funkenstein.

That Clinton's funklore is filled with signifying parody and ribald humor should come as no surprise since these characteristics are trademarks of black vernacular expression. But since "vernacular" is usually interpreted in opposition to intellectualism, it's important to point out that the ideas in Clinton's funklore are conversant with some of the most influential writings in African American literature. For instance, in Toni Morrison's novel The Bluest Eye employs funk in much the same way as Clinton does with Sir Nose. Published the same year Funkadelic was released in 1970, Morrison employs funk as a metaphor for black vernacular sensuality from which the middle-class black women characters of Lorain, Ohio steadfastly recoil. In one of her most famous passages, Morrison writes,

Wherever it erupts, this Funk, they wipe it away; where it crusts, they dissolve it; wherever it drips, flower, or clings, they find it and fight it until it dies. They fight this battle all they way to the grave. The laugh that is a little too loud; the enunciation a little too round; the gesture a little too generous. They hold their behind in for fear of a sway too free; when they wear lipstick, they never cover the entire mouth for fear of lips too thick, and worry, worry, worry about the edges of their hair. ${ }^{58}$

Likewise, scholars generally regard Ishmael Reed's novel Mumbo Jumbo as one of the most complex works of fiction in the history of Western literature. Scholars also agree that Reed challenges Eurocentric epistemology in the novel. Seldom discussed, however, is the striking similarity between the tropes that Clinton and Reed employ, not to mention the critical problems they engage. This similarity isn't coincidental. When asked about his inspiration for his narrative, Clinton replied, "Have you ever read Mumbo Jumbo?"59 Reed uses the ironic term Jes Grew as a trope to represent the funk principle during the Jazz Ages. Early in the novel, which is set in the 1920s, the Mayor of New Orleans rushes to St. Louis Kathedral to inquire about what appears to be a "psychic epidemic," 60 he finds twenty-two people lying on carts, and is given the following report: "[P]eople were doing 'stupid sensual things,' were in a state of 'uncontrollable frenzy,' were wriggling like fish, doing something called the 'Eagle Rock' and 
the 'Sassy Bump'; were cutting a mean 'Mooche,' and 'lusting after relevance.' For the Mayor's cohorts, the 'epidemic' is a plague that they decode as a 'coon Mumbo Jumbo'. ${ }^{\prime 61}$ However, as black poet Nathan Brown says later in the novel, most blacks "are trying their best to catch" 62 Jes Grew because, according to the protagonist Papa LaBas, it's an anti-plague. Both Reed and Clinton satirize the binary logic of Christian philosophy by suggesting that somatic illustrations of the pleasure principle comprise consummate signs of civility.

Like Reed, Clinton also resorts to Egyptian mythology. He revises the conflict between the benevolent sun god Ra and his arch nemesis Set, and recasts Set, who is a symbol of evil and foreign control, as the comedic villain Sir Nose who dwells in the vapid zone of zero funkativity. For Clinton, Sir Nose is a symbolic representation of blacks who associate vernacular dancing with unintelligence because they have adopted racialized views toward black vernacular expression, particularly dancing. And inasmuch as Sir Nose's nasal voice is reminiscent of earlier black comedians' parodies of white speakers, one could also argue that Clinton's representation of social conditioning is compatible with W.E.B. Du Bois's famous double-consciousness theory: "It is a peculiar sensation, this double-consciousness, this sense of always looking at one's self through the eyes of others who look on in amused contempt and pity." So while Clinton worked within the discursive space of popular music, his position in relation to black vernacular epistemology is commensurate with some of the most complex thinkers in black cultural history. ${ }^{63}$

Dr. Funkenstein's mission, then, is manifold: to disrupt constructed normality; to re-educate blacks; to redefine and redirect the racialized joke that Du Bois references; and to lampoon the logic inherent in the caricatures that blacks have historically internalized. Of the numerous art forms in African American culture, dancing has almost certainly been most ridiculed and derided. Such derision has been particularly injurious to blacks not only because dancing has been an effective diversion from dead-end jobs, joblessness, and other forms of alienation, but also because dominant narratives in American culture tend to frame black dancing as indicative of cerebral ineptitude, despite the fact that kinetic orality functions as sign of cognition. As Gaunt points out, "African Americans, male and female, are constantly contending with imposed stereotypes about our social and musical bodies, our somebodiness, as well as the internalized assumptions we carry and impose upon ourselves and other black bodies." ${ }^{\circ 64}$ That funk has received such a paucity of critical attention underscores Gaunt's statement.

We can observe a satirical critique of this form of false consciousness in Parliament's "Flash Light," which appeared on the 1977 album Funkentelechy Vs. the Placebo Syndrome. Having invented the bop gun to zap potential funkateers with quasi-electric beams of the funk, Dr. Funkenstein commissions Star Child to shoot Sir Nose until he experiences an irresistible urge to dance. But Sir Nose remains steadfast in his refusal. ${ }^{65}$ As the song opens, he declares his intention to go to sleep. In Clinton's funklore, sleep symbolizes such a state of unfunkiness that Sir Nose is unable to feel the beat. However, in spite of Sir Nose's prepara- 
tion to count his sheep and thereby avoid kinesis, Star Child is determined to zap him. And when he does, he commands Sir Nose to "[d]ance sucker," while Parlet and the Brides of Funkenstein sing the chorus: "Most of all he needs the funk / help him find the funk." Naturally, Sir Nose's resolve begins to weaken: "Oh funk me!" There are also assorted light-images — neon light, flash light, spot light - which suggest the multitudinous tones of emotional color imbued within p-funk. And though Sir Nose still represses his desire for funkativity after this point, he finally succumbs to the power of the " $p$," proclaiming that he, too, has found pure funk. Sir Nose's proclamations while conjoining his mind, body, and spirit reflect the premise of the song - that the funk is real. Its medicinal qualities are tangible. As Clinton says in "P. Funk (Wants to Get Funked Up)," funk can move and remove, and thereby improve the quality of one's day-to-day existence. This notion is clearly imprinted in the title. Since "entelechy" denotes self-fulfillment, the term "funkentelechy" means to construct the funk in 3-D. Tate describes this state of mind as "hav[ing] your funk low in the saddle and eat[ing]-it-cum-intellectualiz[ing] too." ${ }^{66}$ Thus, funkativity is a style of life that enables people to realize their full potentialities. And while the cultural allusions and argot refer to specific aspects of black working-class culture, the premise of the song is that repression is a Eurocentric construct because all humans have the kinetic desire symbolized by the iridescent rays of Star Child's flashlight. In other words, everyone is blessed with a flicker of "light under the sun."

The battle between Star Child and Sir Nose ensues in "Alpha Boogie (A Psychoalphadiscobetabioaquadooloop)," which appeared the following year on the album Motor Booty Affair. But whereas "Flash Light" encompasses an electricity-trope, water is the primary metaphor in "Aqua Boogie." Featuring the multi-talented singer and intrumentalist Junie Morrison, "Aqua Boogie" is replete with aquatic tropes. And while the water-trope recalls Ellington's trope of liquidity, not to mention the Greek legend of Atlantis, "Aqua Boogie" is also a theoretical vamp on The Swim, a dance that was popular during the early 1960s. Created by Bobby Freeman in 1961, The Swim became so popular that Tina Turner performed it with Ike Turner and the Ikettes. The Swim also served as inspiration for a twenty-one-year-old song writer who would achieve international acclaim as Sly Stone to compose "C'mon and Swim" which became a hit recording three years later in 1964. Clinton elaborates on the works of Freeman and Stone, extending the swim-metaphor to create a funk(y) suite.

"Aqua Boogie," then, suggests the fluid nature of black vernacular dancing. A hyperbolic signifier of choregraphic hipness, the title boasts of rhythms so fly and fluid that one can dance under water without getting wet. Just as water assumes the form of its host, so dancers configure the contours of their somatic vocabularies according to the sensations they feel at a given moment's notice. The song's subtitle, which is reminiscent of jazz musician Yusef Lateef's term "autophysiopsychic music," defies facile elucidation. However, the sundry affixes provide clues. Besides signifying water, "Alpha" is the first letter of the Greek alphabet, and suggests the proverbial "one" in funk music. That "Psycho" 
precedes "alpha" in the subtitle suggests that the mind is indelibly linked to the sensations of the body, and that funk is the cognitive conduit for this fusion. The latter section of the subtitle is even less transparent. The combination of the words "disco" and "beta," which typically connotes testing, suggest a critique of disco music. To put it differently, since Dr. Funkenstein's mission is to reprogram otherwise funkateers, the beta-image implies that disco constituted a discursive faking of the funk. Insofar as its aesthetic imagery and rhythms were squeaky clean and antiseptic, disco was utterly devoid of rhythmic stank. According to Nelson George, "[d]isco's movers and shakers" felt that funk "was too raw and unsophisticated, and one thing dear to the hearts of disco fans ... was a feeling of pseudosophistication." ${ }^{167}$ Thus, Clinton represents likens disco to an unwavering computer programming system which encoded a mechanistic logic and lifestyle which he associates with the dominant superstructure. Likewise, the affixes fusing "bio" (life), "aqua" (funk), and dooloop (repetitive programming) imply that the olfactory chords of the aqua boogie are designed to reprogram unfunky subjects, allowing them to adopt an alternate vision of normality, so that people can learn to accept swimming, that is, funking as natural. As Anne Danielsen states, "According to Clinton, the funk grooves were nothing less than a means of arriving at a spiritual focus while also providing bodily release to an afflicted audience. $"{ }^{68}$

"Aqua Boogie" illustrates the absurdity of the incapacious terms in which blackness is defined. It mocks the notion of a mind/body split as a self-defeating method of responding to black disfranchisement. More fundamentally, though, "Aqua Boogie" foregrounds agency, while positing dancing and musicianship as correlative channels of expression. In other words, the song constructs the funk in order to engage the funky living conditions that blacks experience as direct consequences of the politics of race. This contrariety becomes particularly evident in Morrison's solo ("with the rhythm it takes to dance to what we have to live through") where the singer references choreography in relation to disfranchisement. Thus, "Aqua Boogie" exemplifies the manner in which funk reaffirmed the cultural values and sensibilities of working-class blacks during the 1970s. Here again, the narrative revolves around the arid wallflower Sir Nose who adamantly refuses to learn how swim because he's too cool to get wet. His limited olfactory perception, which is reflected in the nasal timbre of his voice, suggests more broadly his acceptance of standardized definitions of the word "funk," not to mention hegemonic framings of blackness as well. Consequently, he experiences a cognitive dysfunktion when he interfaces the funk-he "can't catch the rhythm of the stroke." But since the meaning of the funk is synonymous with its subcutaneous amelioration, Sir Nose must be rescued from the blahs. Like small children who must be forced to bathe, Nose is physically placed into the water - presumably by Star Child. And much to his surprise, he discovers that he enjoys swimming in water and thereby dancing on the funk: "Oh it feels good." Thus, the band creates superlative doses of funky music that engages 
self-reflexively the problem that it names, while instantiating an ethos and sense of insouciance which enkindle dancers to jam on the good foot.

\section{Conclusion: Think! It Ain't Illegal Yet}

Funk artists rarely emphasized overt notions of black radicalism. But insofar as they transposed the tenets of black power into a philosophy of funk, their music was jam-packed with political significance. After Brown helped to transform previous meanings of blackness to beautification in 1968, singing "I'm black and I'm proud," Funkadelic took it to the stage seven years later, proclaiming "I'm funky and I'm proud." While black activists concentrated on political changes that could be measured concretely (e.g., numerical representations of blacks in corporate, educational, and political institutions), funk artists revolted against staidness and artificiality in American culture at large. Since many blacks had been conditioned to misread affective black phraseologies as uncouth, uncivilized, and unintelligent, they were often repulsed by these expressions. The terms "sanctified" and "holy roller," for instance, which referred to blacks who attended Pentecostal churches, carried a stigma well into the late 1990s. When Sly Stone was a pre-adolescent worshipping with his family outdoors at St. Andrew Church of God in Christ in Denton, Texas during the 1940s, "passersby would throw things at the "hollering' parishioners. ${ }^{969}$ Ramsey reiterates this point when he recalls the mistreatment of sanctified churchgoers during his youth. "When I was growing up," writes Ramsey, "we whispered, 'She's sanctified' behind someone's back with disinterested pity. It was a suitable explanation for why someone who came from a religious family would dress out of date, or otherwise seem a little out of sync with the time." "Y0 Yet groups such as Sly and the Family Stone, Parliament-Funkadelic, the Ohio Players, Lakeside, the Bar-Kays, and others accentuated the very characteristics that blacks had heretofore expressed in the relative obscurity of churches, clubs, dives, and chicken-shacks across the railroad tracks. In a signifying gesture that exemplified such accentuation, the funk mob used the following poster sign as part of an advertisement for a Parliament concert.

\footnotetext{
Notice! Stop! Help Save the Youth of America! Don't Buy NEGRO RECORDS. The screaming, idiotic words, and savage music of these records are undermining the morals of our white youth in America. Call the advertisers of the radio stations that play this type of music and complain to them! Don't let your children buy, or listen to these Negro records. ${ }^{71}$
}

Created in the 1950s, the poster was a kneejerk a response to the resistive potentiality of the irresistible buoyancy of rhythm and blues which was the form in which black organic intellectuals theorized the funk principle at the time. The funk mob's decision to use the advertisement a generation later calls attention 
to continuities among various forms of black popular music and continuities in resistance to the funk. As such, the ad becomes a signifying riff whose denotation is significantly altered in the process of repetition. While the intent of the ad was to promote racial hysteria, Parliament's cooptation of the sign diffused any pernicious effects that might have been associated with it, while exposing the salient contradictions underlying the fear it attempted to foment. In all likelihood, most audience members probably laughed when they saw it. After all, if the mythology of race were really true, that is, if whites were biologically superior they would possess inbred mechanisms that shielded them from the effusive powers of the funk.

The cultural politics encapsulated in Parliament/Funkadelic's rewriting of the poster epitomizes the fundamental rebellion that was encoded in funk music as such. And since funk is inextricably related to kinesis, critical analyses that foreground black dancing repeal the racialized stigmatizations that have customarily been appended to such performances. This critical maneuver removes black dancers from the background of cultural history, and showcases their central roles as organic intellectuals in black vernacular culture. I've already mentioned that Brown led his band as a dancer, and that Mingus's former drummer Richmond was influenced by the tapper Baby Laurence. But it's important to understand that these aren't isolated cases. Nor are they limited to funk music as such. Numerous musicians who have received wide acclaim for their vision and virtuosity, including Ellington and jazz saxophonist Lester Young, have attested to the vital contributions that black vernacular dancers have made in black music. Ellington is quite pointed about this in his commentary on swing drummer and bandleader Chick Webb. Webb's band, which included a young Ella Fitzgerald, was the house band at the Savoy Ballroom, and one of the highlights of the Savoy was the famous battle of the bands in which Ellington's band routinely competed. In the following passage, the Duke explains why he admired Webb. In doing so, he dispels the myth that cerebral acumen and feelings exist in mutual exclusion. Notable also are Ellington's remarks on composer and arranger extraordinaire Billy Strayhorn:

Some musicians are dancers, and Chick Webb was. You can dance with a lot of things besides your feet. Billy Strayhorn was another dancer - in his mind. He was a dancer-writer. Chick Webb was a dancer-drummer who painted pictures of dances with his drums.... If you listen to the figures in some of Strayhorn's pieces, like U.M.M.G," those are dances - tap dances maybe - and you can't mistake what they essentially are." 72

Naturally, some readers may object to my employment of an example from swing to substantiate an argument about funk. But my point here is that the sensing techniques that black dancers employ have been central — not marginal — to 
innovations in black musicianship generally. What was so distinctive about funk was its brazen defiance of social conventions and its insistence on expressing that defiance in black vernacular terms - even if this meant resisting taboos in black culture. As such, the epistemology of funk challenges normative the presumptions and privileges inscribed within received critical models which tend to foreclose investigations that explore the role of human emotion in the production of knowledge. That funk music was created by two dancers, Brown and Stone, simply underscores this point.

In proposing funk as a model for black vernacular intellectualism, then, I hope to further expose the fault lines of class and gender within African American culture. Superlative studies such as Robin D.G. Kelley's Hammer and Hoe: Alabama Communists During the Great Depression (1990) reveal the material conditions that entrap black workers as well as their resourcefulness and commitment to resist such entrapment. However, focusing on black vernacular cognitive modalities also reveals important benefactions of black working-class people that have been rendered opaque and invisible. Examining these modalities divulge forms of agency that have often been misread as indications of false consciousness. To put it differently, engaging the artistry of black vernacular dancers necessarily reveals much of the differential value and prestige that have been denied to them. This is particularly true for black women. Although they comprise a disproportionate majority of dancers in churches, house parties, clubs, and other performative arenas, black women are virtually invisible in critical discussions of black musicianship. They have been similarly excluded from the mentorship processes whereby black instrumentalists have developed their craft, and I believe that these two exclusions are interrelated. A similar argument can be made regarding black vernacular dancers overall. Situating black dancing within the framework of black vernacular intellectual history allows us to observe conceptual contributions and expressions of assertiveness that we might otherwise overlook.

Again, Brown serves as a prime example. Reflecting on the historical milieu in which he wrote "New Bag," Brown noticed a discernible discrepancy between the music that represented black culture and the resistive spirit of the youth who were rebelling in the streets and participating in the Civil Rights movement. For Brown, "New Bag" was "a way to choreograph the burgeoning pride that could be felt everywhere." "73 Notwithstanding Brown's 1968 recording "Say It Loud-I'm Black And I'm Proud," his reputation as a political conservative rests largely on his espousal of black capitalism and his refusal to support violent means of resisting state violence. But while Brown is certainly accountable for his political contradictions, he never claimed to be a political theorist. He was, however, a quintessential scientist of sound, and the rhythm nation which was adumbrated within Brown's dance-beat aesthetic influenced the Nigerian musician and activist Fela Kuti's blueprint for Afrobeat, which is widely recognized today as an international musical genre. That it did so is an indelible testimony to the agency lodged deep within the sediments of funk. 


\section{Notes}

1. George Clinton, qtd. in Rickey Vincent, Funk: The Music, the People, and the Rhythm of the One (New York: St. Martin's Press, 1996), 13.

2. Teresa L. Reed, The Holy Profane: Religion in Black Popular Music (Lexington: University of Kentucky Press, 2003), 15. See also, Mark Anthony Neal, "Sly Stone and the Sanctified Church," The Funk Era and Beyond: New Perspectives on Black Popular Culture. Ed. Tony Bolden (New York: Palgrave/Macmillan, 2008), 3-9. For alternative approach, see Scot Brown's analysis of the role that public schools in Dayton, Ohio played in the development of funk musicians. Scot Brown, "A Land of Funk: Dayton, Ohio," The Funk Era and Beyond: New Perspectives on Black Popular Culture. Ed. Tony Bolden (New York: Palgrave/Macmillan, 2008), 73-88.

3. Teddy Pendergrass, Truly Blessed (New York: Putnam Adult, 1998), 34.

4. Guthrie P. Ramsey, Race Music: Black Cultures from Bebop to Hip Hop (Berkeley: University of California Press, 2004), 13.

5. James Brown, "Papa's Got A Brand New Bag, Pts. 1, 2, \& 3," 1965. James Brown Star Time Box Set Edition, Polydor, 842 108-2, 1991.

6. James Brown, qtd. in Lyn Collins, "Interview," Mama Feelgood, Hi \& Fly Records, 2006. It's also notable that scholars of go-go music have made similar parallels between go-go and Pentecostal music. See Kip Lornell and Charles C. Stephenson, Jr., The Beat: Go-Go Music from Washington, D.C. (Reprint. Jackson, MS: University Press of Mississippi, 2009). See also, Natalie Hopkinson, Go-Go Live: The Musical Life and Death of a Chocolate City (Durham: Duke University Press, 2012). According to Hopkinson, "Go-go can feel a lot like a Pentecostal church service. ... Neither erects a huge barrier between who is performing and who is watching. Both are heavy in call and response" (51). See also, Glen Hinson, Fire in My Bones: Transcendence and the Holy Spirit in African American Gospel (Philadelphia: University of Pennsylvania Press, 1999).

7. Paul Taylor, “An Interview with Nathaniel Mackey," Callaloo 23.2 (Spring 2000): 645.

8. Barbara Christian, "The Race for Theory," Making Face, Making Soul/Haciendo Caras: Creative and Critical Perspectives by Feminists of Color, Ed. Gloria Anzaldua (San Francisco: Aunt Lute Books, 1990), 336.

9. John Miller Chernoff, "The Artistic Challenge of African Music: Thoughts on the Absence of Drum Orchestras in Black American Music," Black Music Research Journal 5 (1985): 2.

10. Rickey Vincent, Funk: The Music, the People, and the Rhythm of the One (New York: St. Martin's Press, 1996), 4.

11. Jonathan David Jackson, "Improvisation in African-American Vernacular Dancing," Dance Research Journal 33.2 (Winter 2001-2002): 43.

12. Forrest, Leon, The Furious Voice: Essays on Life (Wakefield, RI: Asphodel Press, 1994), 46.

13. See Olly Wilson, "The Association of Movement and Music as a Manifestation of a Black Conceptual Approach to Music-Making,"More Than Dancing: Essays on Afro-Americn Music and Musicians. Ed. Irene V. Jackson (Westport, CT: Greenwood Press, 1985), 9-23. Amiri Baraka makes a similar observation about jazz musician Charlie Parker, stating that "Parker did not admit that there was any separation between himself and the agent he had chosen as his means of self-expression." See Baraka, Blues People: Negro Music in White America (New York: Morrow, 1963), 30-31.

14. Kyra D. Gaunt, The Games Black Girls Play: Learning the Ropes from Double-Dutch to Hip-Hop (New York: New York University Press, 2006), 59.

15. This cognitive modality was prefigured by the principle of ashe, which literally means "so be it," in traditional African cultures. For a detailed analysis of this principle, see Robert Farris Thompson, Flash of the Spirit (New York: Vintage, 1984).

16. Thomas F. DeFrantz, "The Black Beat Made Visible: Hip Hop Dance and Body Power," Of the Presence of the Body: Essays on Dance and Performance Theory. Ed. Andre Lepecki (Middleton, CT: Wesleyan University Press, 2004), 66.

17. Thomas DeFrantz, "The Black Beat Made Visible," p. 66.

18. Gaunt, 62.

19. Natalie Hopkinson, Go-Go Live: The Musical Life and Death of a Chocolate City (Durham, Duke University Press, 2012), 42.

20. Gaunt, 98 .

21. Ibid.

22. The dance vocabulary of The Moonwalk has a long history. In The Godfather of Soul: An Autobiography, James Brown distinguishes The Camel Walk from The Moonwalk by pointing out that the latter dance "is really the bicycle, a move Charlie Chaplin used to do. You know how you get on a bicycle and ride it backwards? That's the moonwalk - the Charlie Chaplin bicycle done backwards." See James Brown, The Godfather of Soul: An Autobiography (Reprint. New York: Thunder's Mouth Press, 1997), 55. Brown's commentary notwithstanding, Michael Holman suggests that the basic dance vocabulary of the dance was performed as far back as 1872 . Writing about a dance that appeared a generation later, Holman states, "A dance that appeared around the turn of the century in Black minstrel shows called Stepping on the Puppy's Tail also had an amazing resemblance to the moon walk. Stepping on the Puppy's Tail was described as moving each foot 
alternately backwards "like a horse pawing the ground" (33). See Michael Holman, "Breaking: The History" That's the Joint!: The Hip-Hop Studies Reader. Eds. Murray Forman and Mark Anthony Neal (New York: Routledge, 2004), 13-20. Other notable examples include Bill Bailey's version in the 1943 film Cabin in the Sky. In 1955, Bailey performed an extended version that's nearly identical to Jackson's dance. http://www.youtube.com/watch?v=y71njpDH3co. (Retrieved September 29, 2013). Verta Mae Grosvenor's version also comes to mind. Grosvenor developed hers during her tenure as a dancer with jazz musician Sun Ra's band. She states, "I developed the Space Walk, the one that Michael Jackson did later and called it the "moon walk." See Tony Bolden "Theorizing the Funk: An Introduction," The Funk Era and Beyond: New Perspectives on Black Popular Culture. Ed. Tony Bolden (New York: Palgrave/Macmillan, 2008), 20. Finally, according to Ericka Blount Danois, "Michael Jackson invited [Soul Train] dancers to his home to teach him how to do the robot (and later the moonwalk)." See Danois's book Love, Peace, and Soul: Behind the Scenes of America's Favorite Dance Show Soul Train: Classic Moments (Milwaukee: Backbeat Books, 2013), 46

23. Many scholars interpret the ability to create dynamic expression while maintaining an impassive exterior as an aesthetic of the cool. For a detailed discussion, see Thompson, Flash of the Spirit.

24. Portia K. Maultsby, "Dayton Street Funk: The Layering of Multiple Identities," The Ashgate Research Companion to Popular Musicology. Ed. Derek B. Scott (Burlington, VT: Ashgate, 2009), 268.

25. Jacqui Malone, Steppin' on the Blues: The Visible Rhythms of African American Dance (Urbana: University of Illinois Press, 1996), 95-96.

26. See Howard Spring, "Swing and the Lindy Hop: Dance, Venue, Media, and Tradition," American Music (Summer 1997): 183-207. According to Spring, "The first public reference to the Lindy Hop occurred in 1928, just before the music started to change. This suggests, at least at the beginning, that the dance set off changes in the music. Once set in motion, the nature of the process was one of mutually influential feedback between dancers and musicians ..." (184).

27. This approach can be found in hip hop as well. As Joseph Schloss points out, “[T] he value of a groove is often felt in the body through the oft-cited 'head nodding' or through dance ..." (143). Schloss then quotes producer Negus I, who correlates dancing with the art of producing: ". . . I think it also helps to be a dancer, to dance a lot. . . . If you dance a lot, you know what's going to move you to dance. And so, when you're making a beat, that's gonna help you a lot. As opposed to something that sounds good, something that feels good is really important (143). Although I'm skeptical of the opposition between sound and feeling, Negus I's comments are nonetheless helpful in understanding how dancing can inform a musician's approach to sound. There are numerous examples of similar statements by black musicians. See Joseph Schloss, Making Beats: The Art of Sample-Based Hip-Hop (Middletown, CT: Wesleyan University Press, 2004).

28. Bootsy Collins, qtd. in Thomas Sayers Ellis, "From the Crib to the Coliseum: An Interview with Bootsy Collins," The Funk Era and Beyond: New Perspectives on Black Popular Culture. Ed. (New York: Palgrave/Macmillan, 2008), 91.

29. Alan Leeds, qtd. in Make It Funky, Yvonne Smith. Director and writer. PBS, 1995.

30. Zora Neale Hurston, "Characteristics of Negro Expression," The Jazz Cadence of American Culture, Ed. Robert O’Meally (New York: Columbia University Press, 1998), 302. Brown's biographer R.J. Smith corroborates the statements by Bootsy Collins and Alan Leeds in his discussion of drummer Jabo Starks's efforts to learn Brown's show. See R.J. Smith, The One: The Life and Music of James Brown. New York: Gotham Books, 2012.

31. James Brown, I Feel Good: A Memoir of a Life of Soul (New York: NAL, 2005), 80.

32. Brown, I Feel Good, 79.

33. Brown, I Feel Good, 84.

34. Olly Wilson, “'It Don’t Mean a Thing if It Ain’t Got That Swing': The Relationship Between African and African American Music," African Roots/American Cultures: Africa in the Creation of the Americas, Ed. Sheila S. Walker (Lanham, Md.: Rowman and Littlefield Publishers, 2001), 167.

35. Natalie A. Hopkinson, Go-Go Live, p. 51 I'm also reminded here of Kool and the Gang's "Hollywood Swinging." Wild and Peaceful, Mercury Records, 1973.

36. Stanley Dance, The World of Count Basie (New York: DaCapo, 1985), 157. My italics.

37. Hip hop heads will naturally recognize an affinity between Ellington's liquid-metaphor and the concept of flow in MCing. Recently, the singer Gregory Porter employed a variation of this trope in the title song of his album Liquid Spirit. Blue Note Records, 2013.

38. Duke Ellington, qtd. in Ken Rattenbury, Duke Ellington, Jazz Composer (New Haven, CT: Yale University Press, 1990), 14. italics.

39. Maceo Parker, qtd. in Make It Funky, Yvonne Smith. Director and writer. PBS, 1995. My

40. James Brown, I Feel Good, 81.

41. James Brown, I Feel Good, 87. 30,2011 .

42. George Clinton, qtd. on "The Tavis Smiley Show." Aired on PBS in Lawrence, KS July 
43. I'm reminded of a statement by Nathaniel Mackey that seems pertinent here. In his interview with Paul Taylor, Mackey finds a correlation between the contrariety of funk music and the epistemological premises of such noted intellectuals as the Guyanese novelist and essayist Wilson Harris and the French philosopher and novelist Catherine Clément. Mackey also discerns an implicit social critique in such contrariety. Having mentioned Harris in the previous sentence, Mackey states, "I was struck . . . by Catherine Clement's discussion, in Syncope, of a reversal or distillation of odors, the saint's, the yogi's or the mystic's transformation of the fetid odors of bodily exertion, breakdown or putrefaction into spiced aromas, floral aromas. She in fact says that the saint, the yogi and the mystic are "living perfume bottles." I couldn't help thinking of this in relation to funk, the African American transformation of offensive odor into a canon of approval, aesthetic approbation, an analogously mystical distillation of the otherwise or ostensibly offensive into perfume. There's also a social, cultural critique bound up in this" (649). See Paul Taylor, "An Interview with Nathaniel Mackey," Callaloo 23.2 (Spring 2000): 645-664.

44. The relative indifference from blacks toward Parliament-Funkadelic during its early years is one of the fascinating ironies of black cultural history. As the drummer Frank "Kash" Waddie recalls, in the early phase of Parliament/Funkadelic, "we had an all-White fan base. Then when funk became a household word, then they shipped us a Black act! . . . One guy [from the label] finally told us the truth, and said, 'Hey man, these guys don't want you to leap over to surburbia, they just want you to do well in urbana." See Matt Rogers, "Trap Music: Drummer Frankie "Kash" Waddy Stays on the One." Wax Poetics 18 (2006): 96-100.

45. Jimi Hendrix, qtd. in Bob Smeaton, Jimi Hendrix-Band of Gypsys: Live at Fillmore East, Experience Hendrix, 2011.

46. Fayne Pridgeon, qtd. in Joe Boyd and John Head, Jimi Hendrix. Warner Bros, 1973. Hendrix's brother, Leon Hendrix, has suggested that Hendrix's appeal among blacks may have been underreported. He recalls, "I suspected that the people who complained the most about my brother's music being popular with the white kids probably had his records stashed away somewhere in a closet and still listened to it at home at night" (125). See Leon Hendrix with Adam Mitchell, Jimi Hendrix: A Brother's Story (New York: Thomas Dunne Books, 2012).

47. Frankie "Kash" Waddy, qtd. in Matt Rogers, "Trap Music: Drummer Frankie "Kash" Waddy Stays on the One." Wax Poetics 18 (2006): 100. 184.

48. Leon Hendrix, Jimi Hendrix: A Brother's Story (New York: Thomas Dunne Books, 2012),

49. Greg Tate, Midnight Lightning: Jimi Hendrix and the Black Experience (Chicago: Chicago Review Press, 2003), 39.

50. Bootsy Collins, qtd. in Rickey Vincent, "The History of Funk Show." http://www.kpfa. org/history-funk. Retrieved November 25, 2011.

51. Tate, Midnight Lightning, 29.

52. Calvin Simon, qtd. in Dave Marsh, George Clinton and P-Funk: An Oral History (New York: Avon Books, 1998), 55.

53. George Clinton, qtd. in Dave Thompson, Funk: Third Ear-The Listening Companion (New York: Backbeat Books, 2001), 87.

54. George Clinton, qtd. in Dave Thompson, Funk, 42. My italics.

55. George Clinton, qtd. in Dave Marsh, George Clinton, 82.

56. Leon Forrest, Furious Voices, 45.

57. Jeanette Washington, qtd. in Dave Marsh, George Clinton, 101.

58. Toni Morrison, The Bluest Eye (Reprint. New York: Random House, 1993), 68.

59. George Clinton, qtd. in Rickey Vincent, Funk, 177.

60. Ishmael Reed, Mumbo Jumbo (New York: Scribner, 1972), 5.

61. Reed, Mumbo Jumbo, 4.

62. Reed, Mumbo Jumbo, 117.

63. It's also worth noting here that Clinton's theory of the funk is remarkably similar to Du Bois's notion of the "frenzy" in his 1903 essay "Of the Faith of the Fathers." Recalling his initial experience of witnessing spirituality in a black southern church, Du Bois notes that the frenzy seized devotees with supernatural joy, and that the shrieks, shouts, and trances he witnessed weren't peculiar to blacks, but that "so firm a hold did it have on the Negro, that many generations firmly believed that without this visible manifestation of the God there could be no true communion with the Invisible" (Souls 142). See W.E.B. Du Bois, "Of the Faith of the Fathers," The Souls of Black Folk (Cutchogue, NY: Buccaneer Books, 1976 [1903]), 140-151.

64. Gaunt, 5.

65. In positing electricity as a metaphor for the funk, Clinton is employing virtually the same trope as blues and jazz musicians in previous periods. See "Theorizing the Funk: An Introduction." The Funk Era and Beyond: New Perspectives on Black Popular Culture. Ed. Tony Bolden (New York: Palgrave/Macmillan, 2008), 13-29.

66. Greg Tate, Flyboy in the Buttermilk: Essays on Contemporary America (New York: Simon and Schuster, 1992), 17. 


\section{Tony Bolden}

67. Nelson George, The Death of Rhythm and Blues (Reprint. New York: Penguin, 2003), 154.

68. Anne Danielsen, Presence and Pleasure: Funk Grooves of James Brown and Parliament (Middleton, CT: Wesleyan University Press, 2006), 115

69. Jeff Kaliss, I Want to Take You Higher: The Life and Times of Sly and the Family Stone (Milwaukee: Backbeat Books, 2008), 4.

70. Guthrie P. Ramsey, Race Music, 11.

71. Qtd. in Thomas Sayers Ellis, The Maverick Room: Poems (Minneapolis: Graywolf Press, 2004), 16

72. Duke Ellington, Music Is My Mistress (Cambridge: Da Capo, 1976), 100.

73. James Brown, I Feel Good, 81. 